\title{
Article \\ Continuous LED Lighting Enhances Yield and Nutritional Value of Four Genotypes of Brassicaceae Microgreens
}

\author{
Tatjana G. Shibaeva *(D), Elena G. Sherudilo, Alexandra A. Rubaeva and Alexander F. Titov
}

check for updates

Citation: Shibaeva, T.G.; Sherudilo, E.G.; Rubaeva, A.A.; Titov, A.F. Continuous LED Lighting Enhances Yield and Nutritional Value of Four Genotypes of Brassicaceae Microgreens. Plants 2022, 11, 176. https://doi.org/ $10.3390 /$ plants 11020176

Academic Editor: Eva Darko

Received: 24 December 2021

Accepted: 7 January 2022

Published: 10 January 2022

Publisher's Note: MDPI stays neutral with regard to jurisdictional claims in published maps and institutional affiliations.

Copyright: (C) 2022 by the authors. Licensee MDPI, Basel, Switzerland. This article is an open access article distributed under the terms and conditions of the Creative Commons Attribution (CC BY) license (https:// creativecommons.org/licenses/by/ $4.0 /)$.
Institute of Biology, Karelian Research Center, Russian Academy of Science, 185910 Petrozavodsk, Russia; sherudil@krc.karelia.ru (E.G.S.); leksa_2018@mail.ru (A.A.R.); titov@krc.karelia.ru (A.F.T.)

* Correspondence: shibaeva@krc.karelia.ru

\begin{abstract}
The effect of continuous lighting (CL, $24 \mathrm{~h})$ and light spectrum on growth and nutritional quality of arugula (Eruca sativa), broccoli (Brassica oleracea var. italic), mizuna (Brassica rapa. var. nipposinica), and radish (Raphanus sativus var. radicula) were investigated in growth chambers under light-emitting diode (LED) and fluorescent lighting. Microgreens were grown under four combinations of two photoperiods ( $16 \mathrm{~h}$ and $24 \mathrm{~h}$ ) providing daily light integral (DLI) of 15.6 and $23.3 \mathrm{~mol} \mathrm{~m}^{-2}$ day $^{-1}$, correspondingly) with two light spectra: LED lamps and fluorescent lamps (FLU). The results show that fresh and dry weights as well as leaf mass per area and robust index of harvested arugula, broccoli, mizuna, and radish seedlings were significantly higher under CL compared to $16 \mathrm{~h}$ photoperiod regardless of light quality. There were no visible signs of leaf photodamage. In all CL-treated plants higher chlorophyll $a / b$ and carotenoid-to-chlorophyll ratios were observed in all plants except mizuna. CL treatment was beneficial for anthocyanin, flavonoid, and proline accumulation. Higher activities of antioxidant enzymes (catalase, superoxide dismutase, ascorbate peroxidase, and guaiacol peroxidase) were also observed in CL-treated plants. In most cases, the effects were more pronounced under LED lighting. These results indicate that plants under mild oxidative stress induced by CL accumulated more non-enzymatic antioxidants and increased the activities of antioxidant enzymes. This added nutritional value to microgreens that are used as functional foods providing health benefits. We suggest that for arugula, broccoli, mizuna, and radish, an LED CL production strategy is possible and can have economic and nutritional benefits.
\end{abstract}

Keywords: continuous lighting; photoperiod; spectral quality; light-emitting diodes; microgreens; functional food

\section{Introduction}

Microgreens are a relatively new specialty crop and emerging commodity in worldwide markets. They are defined as tender immature greens produced from seeds of vegetables, herbs, or gains, including local varieties and wild species having fully developed cotyledons with or without the emergence of a rudimentary pair of first true leaves $[1,2]$. Microgreen production is attractive to growers due to the increasing demand and high market value [3]. Microgreens are mainly used by chefs and consumers to enhance the color, flavor, texture, and nutritional value of various foods. Microgreens have a limited postharvest shelf life; therefore, local production, especially for fresh-cut products, represents the most promising production strategy [4]. Several species of microgreens are known for their health beneficial effects as they contain high concentrations of health-promoting phytochemicals [1,5]. Their bioactives include higher levels of antioxidant compounds such as polyphenols, carotenoids, and ascorbic acid, than their mature plants, thus qualifying microgreens as functional food [1,6].

Nowadays, growers produce microgreens in greenhouses and in plant factories with artificial lighting [7,8]. Indoor vertical farming is an environmentally sustainable form of plant production because of its high land and water resource use efficiency [8-10]. In controlled environment agriculture, such as greenhouses and plant factories with artificial 
lighting (PFAL), natural sunlight is supplemented or replaced with electrical lighting. Generally, lighting cost directly leads to higher production cost as it accounts for $70-80 \%$ of the total electricity consumption in PFAL [11]. Thus, it is necessary to reduce lighting cost through improving the lighting system with well-designed photosynthetic photon flux density (PPFD), photoperiod, spectrum, and control strategy. Although fluorescent (FLU) lamps were initially used as the standard light source in multilayer vertical growing systems, growers have begun replacing them with light-emitting diodes (LED). Compared to other artificial light sources, LEDs offer many advantages including low radiant heat output, low energy requirement, very fast response time, tunability, and long lifespan $[12,13]$. The availability of a large variety of narrowband-emitting diodes may allow for the scheduled induction of spectral-dependent physiological responses of plants, ensuring the optimal light setting for both crop yield and quality [14]. LED technology has shown a great potential to stimulate plant growth and the synthesis of bioactive compounds beneficial to human health $[15,16]$. With the advent of LED lighting fixtures and programmable control systems, the timing and intensity of horticultural lighting can be controlled more precisely than ever before. However, the selection of optimal lighting conditions for the growth of different plant species is far from resolved. Very little attention has been paid to the role of light quality in phytonutrient content of dietary plants [16]. Extensive literature data highlight varying responses of plants to different light settings even when same light conditions are applied to different species [17]. Therefore, an evaluation of the plant response to the light environment should be performed for each species as well as the growing conditions if the target is to maximize efficiency, yield, and quality of plants.

As artificial lighting for growing plants is expensive, the solutions should be aimed to increase the efficiency of energy conversion into yield and quality [18]. One possible way to increase light efficiency in PFAL is extending the duration of lighting period. The use of long photoperiods (up to $24 \mathrm{~h}$ a day-continuous light, $\mathrm{CL}$ ) is the pinnacle utilization of lighting as it provides continuous, $24 \mathrm{~h}$ of radiation to the crop. Theoretically, the use of CL provides constant energy for carbon assimilation, meaning larger biomass accumulation and yield [19]. Furthermore, the implementation of a supplemental CL strategy can have a positive economic implication as well [18] if no photo-injury occurs. However, the use of CL on plant cultivation presents a challenge, because plant responses are contradictory and are far from being fully understood. Past studies with conventional light sources have shown that long photoperiods of lighting cause photo-injury - leaf chlorosis, and reduction in leaf photosynthesis and yield in vegetable crops such as tomatoes, eggplant, cucumbers, and peppers, which have limited the application of this economically favorable lighting strategy in greenhouse vegetable production [20-22]. Recent research has shown that CL delivered by LEDs of different intensities and spectral quality can be used to improve yield and nutritional quality of lettuce plants by reducing nitrate content and enhancing phytochemical concentrations and antioxidant capacity [23-26].

Although previous reports have indicated that light intensity or light quality had an effect on the growth of microgreens, to our knowledge, little work has been published on the interaction between photoperiod, light intensity, and light quality on the growth and nutrient content of microgreens. This study investigated the physiological, growth, and yield response of four genotypes of Brassicaceae microgreens (arugula, broccoli, mizuna, and radish) to CL with different spectral quality (LED and FLU) under fully controlled growth conditions. Our aims were to test if $C L$, in combination with specific light spectra, could increase yield and nutritional value of the microgreens with respect to a $16 \mathrm{~h}$ photoperiod and determine if the response is dependent on light spectrum.

\section{Results}

\subsection{Plant Growth and Yield}

CL over a 9-day cycle (from day 4 after sowing to harvest), with two different light spectra (FLU and LED) and at $270 \mu \mathrm{mol} \mathrm{m}{ }^{-2} \mathrm{~s}^{-1}$ of PAR neither impaired growth of four microgreens nor caused visual photodamage to the leaves. The growth and productivity of 
arugula, broccoli, mizuna, and radish plants were significantly affected by CL (Table 1). CLgrown plants outperformed plants grown under $16 \mathrm{~h}$ photoperiod in terms of production of fresh weight (FW) and dry weight (DW), except for mizuna in FLU-CL treatment. Plants in both CL treatments had much higher leaf mass per area (LMA). CL increased the growth and productive performances of plants with minor effects depending on the light quality applied.

Table 1. Growth characteristics of microgreens grown under $16 \mathrm{~h}$ photoperiod or continuous light provided by fluorescent (FLU) lamps or LEDs.

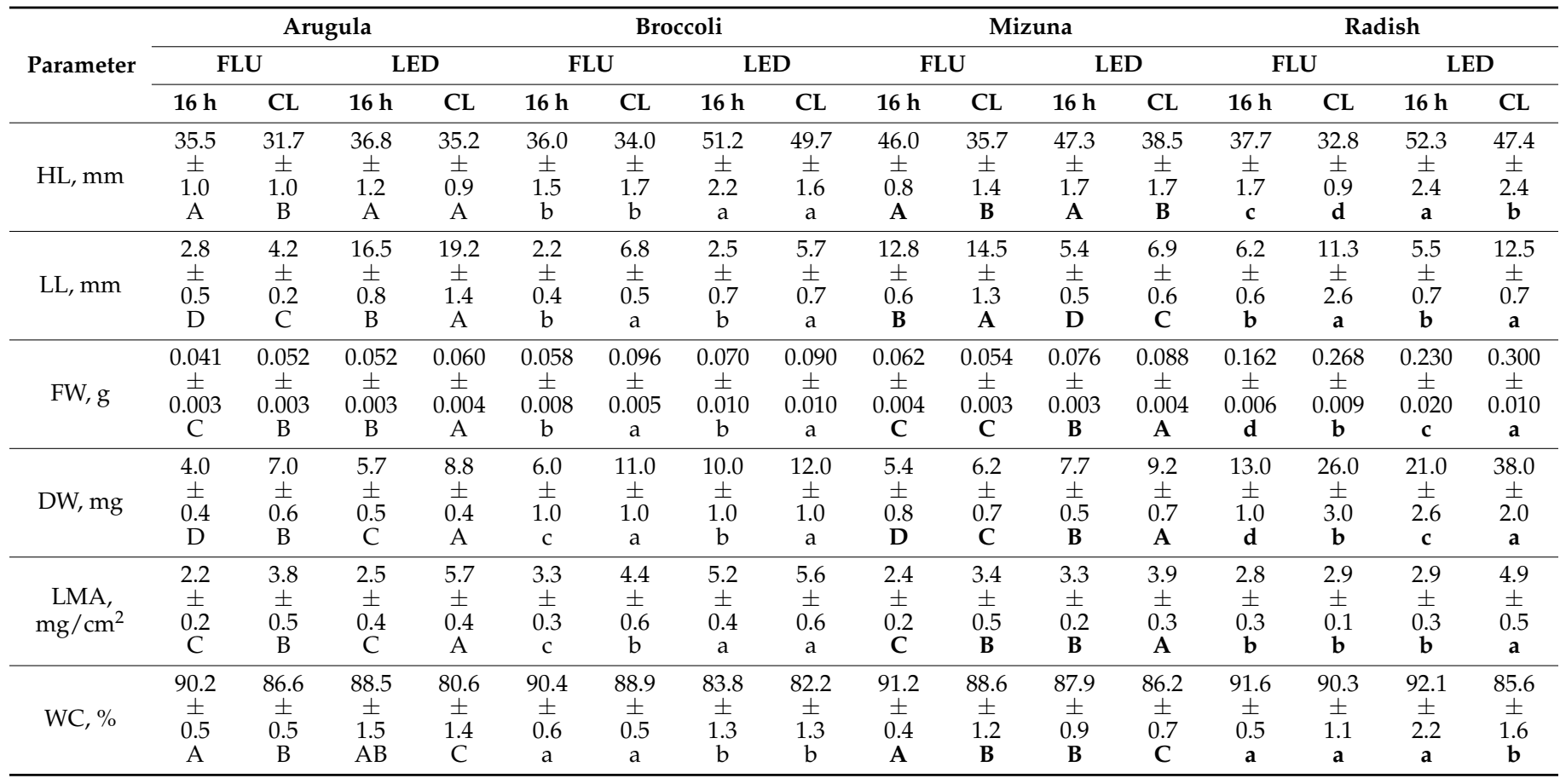

HL-hypocotyl length, LL—first true leaf length, FW—fresh weight, DW—dry weight, LMA—leaf mass per area. WC - water content. Different letters for each plant species indicate significant differences between the mean values at $p<0.05$.

Plants under CL were shorter, and although, not always, the differences between $16 \mathrm{~h}$ photoperiods and CL were significant (Table 1 ). The more pronounced decrease in hypocotyl length (HL) was observed in FLU treatments.

Robust index (RI) was significantly higher in all CL-treated plants both in FLU and LED treatments (Figure 1). There was no effect of treatments on the hypocotyl diameter (HD).

Water content (WC) of microgreens was not significantly influenced by CL (Table 1), with the exception of LED-CL-treated arugula and radish plants, which was 9 and $7 \%$ lower WC compared to control plants grown under $16 \mathrm{~h}$ photoperiod, respectively.

The length of the first true leaf (LL) was higher in all microgreen plants treated by CL regardless of light quality, and effect was the greatest (up to 2-3-fold) in broccoli and radish (Table 1).

\subsection{Photosynthetic Pigments}

CL decreased total chlorophyll (Chl) content in arugula and mizuna, but not in broccoli and radish (Table 2). Arugula and mizuna plants in FLU treatments were more sensitive and lost more Chl compared to LED-illuminated plants. Similar trend was observed for carotenoid (Car) content. Higher levels of $\mathrm{Chl} a / b$ ratio (Figure 2) and Car/Chl ratio (Figure 3) were observed for LED-CL treatments. 


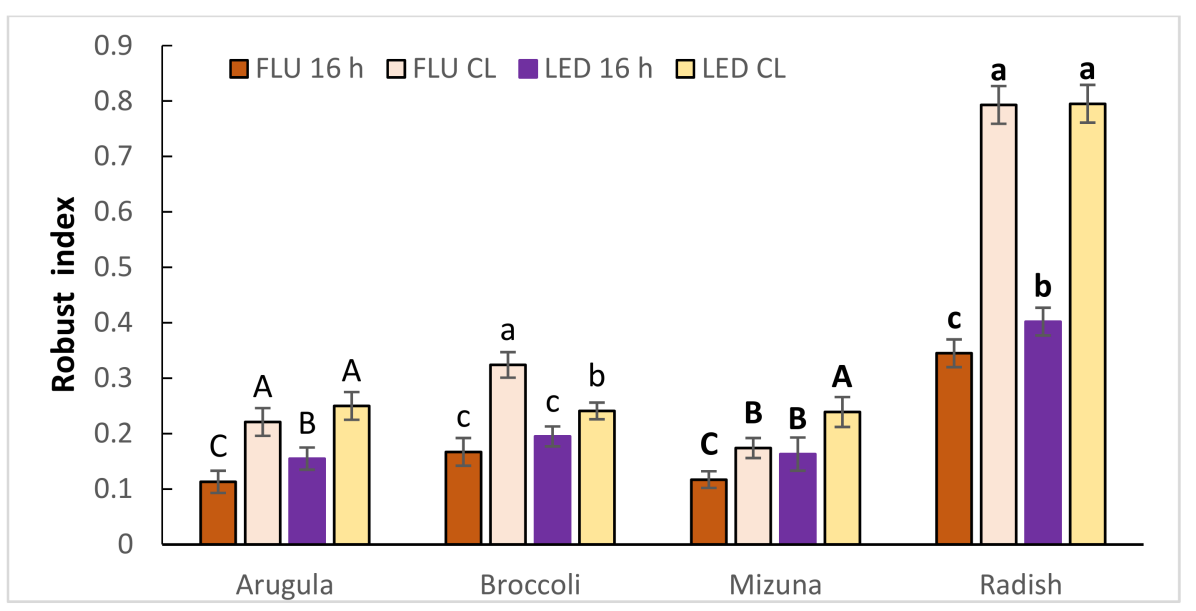

Figure 1. The robust index of arugula, broccoli, mizuna and radish microgreens grown under $16 \mathrm{~h}$ photoperiod or CL provided by fluorescent (FLU) or LED lamps. The results are presented as the mean \pm standard error. Different letters for each plant species indicate significant differences between the mean values at $p<0.05$.

Table 2. Leaf chlorophyll $(a+b)$ content, share of chlorophyll in light-harvesting complex II (LHCII), carotenoid, anthocyanin, and flavonoid contents of microgreens grown under $16 \mathrm{~h}$ photoperiod or continuous light provided by fluorescent (FLU) lamps or LEDs.

\begin{tabular}{|c|c|c|c|c|c|c|c|c|c|c|c|c|c|c|c|c|}
\hline \multirow{3}{*}{ Parameter } & \multicolumn{4}{|c|}{ Arugula } & \multicolumn{4}{|c|}{ Broccoli } & \multicolumn{4}{|c|}{ Mizuna } & \multicolumn{4}{|c|}{ Radish } \\
\hline & \multicolumn{2}{|c|}{ FLU } & \multicolumn{2}{|c|}{ LED } & \multicolumn{2}{|c|}{ FLU } & \multicolumn{2}{|c|}{ LED } & \multicolumn{2}{|c|}{ FLU } & \multicolumn{2}{|c|}{ LED } & \multicolumn{2}{|c|}{ FLU } & \multicolumn{2}{|c|}{ LED } \\
\hline & $16 \mathrm{~h}$ & CL & $16 \mathrm{~h}$ & CL & $16 \mathrm{~h}$ & CL & $16 \mathrm{~h}$ & CL & $16 \mathrm{~h}$ & CL & $16 \mathrm{~h}$ & CL & $16 \mathrm{~h}$ & CL & $16 \mathrm{~h}$ & CL \\
\hline \multirow{4}{*}{$\begin{array}{c}\mathrm{Chl} a+b \\
\mathrm{mg} / \mathrm{mg} \mathrm{DW}\end{array}$} & 12.9 & 6.8 & 12.3 & 9.6 & 6.6 & 7.2 & 9.0 & 8.1 & 8.8 & 6.3 & 5.4 & 4.4 & 7.3 & 7.8 & 6.5 & 6.2 \\
\hline & \pm & \pm & \pm & \pm & \pm & \pm & \pm & $\begin{array}{l}0.1 \\
\pm\end{array}$ & \pm & \pm & $\begin{array}{l}J . I \\
\pm\end{array}$ & $\begin{array}{l}1.1 \\
\pm\end{array}$ & \pm & \pm & \pm & $\begin{array}{l}0.2 \\
\pm\end{array}$ \\
\hline & 0.1 & 0.2 & 0.7 & 0.4 & 0.7 & $\frac{1}{0.3}$ & 0.3 & 0.6 & 1.1 & 0.3 & 0.3 & 0.2 & $\stackrel{ \pm}{0.5}$ & $\stackrel{ \pm}{0.5}$ & $\stackrel{ \pm}{0.2}$ & 0.3 \\
\hline & A & $\mathrm{C}$ & A & B & $\mathrm{b}$ & $\mathrm{b}$ & $\mathrm{a}$ & $\mathrm{ab}$ & A & B & $\mathrm{C}$ & D & a & a & b & b \\
\hline \multirow{4}{*}{ LHCII, \% } & 56.5 & 56.9 & 63.6 & 54.6 & 68.8 & 68.5 & 65.9 & 59.6 & 52.6 & 53.9 & 65.7 & 70.8 & 71.3 & 74.1 & 66.1 & 59.1 \\
\hline & \pm & \pm & \pm & \pm & \pm & \pm & \pm & \pm & \pm & \pm & \pm & \pm & \pm & \pm & \pm & \pm \\
\hline & 0.5 & 0.8 & 3.6 & 3.4 & 2.1 & 3.6 & 4.3 & 3.8 & 1.0 & 0.71 & 3.8 & 2.5 & 4.4 & 4.4 & 3.1 & 2.7 \\
\hline & B & B & A & B & $\mathrm{a}$ & a & $\mathrm{a}$ & $\mathrm{a}$ & B & B & A & A & $\mathbf{a}$ & a & b & b \\
\hline \multirow{4}{*}{$\begin{array}{l}\text { Carote-noids, } \\
\mathrm{mg} / \mathrm{mg} \text { DW }\end{array}$} & 1.9 & 1.1 & 0.7 & 0.9 & 0.8 & 0.9 & 1.2 & 1.3 & 1.4 & 1.1 & 0,4 & 0,2 & 0.8 & 0.9 & 0.8 & 1.0 \\
\hline & \pm & \pm & \pm & \pm & \pm & \pm & \pm & \pm & \pm & \pm & \pm & \pm & \pm & \pm & \pm & \pm \\
\hline & 0.1 & 0.1 & 0.1 & 0.1 & 0.1 & 0.1 & 0.1 & 0.1 & 0,1 & 0.1 & 0.1 & 0.1 & 0.1 & 0.1 & 0.1 & 0.1 \\
\hline & A & B & $\mathrm{C}$ & B & $\mathrm{C}$ & $\mathrm{b}$ & $\mathrm{a}$ & $\mathrm{a}$ & A & B & C & D & b & $\mathbf{a}$ & $\mathbf{b}$ & $\mathbf{a}$ \\
\hline \multirow{4}{*}{$\begin{array}{c}\text { Anthocy- } \\
\text { anins, } \\
\text { mg/mg FW }\end{array}$} & 1.4 & 2.0 & 1.7 & 5.7 & 1.5 & 2.6 & 1.3 & 2.5 & 0.3 & 0.8 & 0.3 & 0.5 & 0.2 & 0.4 & 0.2 & 0.4 \\
\hline & \pm & \pm & \pm & \pm & \pm & \pm & \pm & \pm & \pm & \pm & \pm & \pm & \pm & \pm & \pm & \pm \\
\hline & 0.1 & 0.5 & 0.2 & 0.2 & 0.2 & 0.6 & 0.5 & 0.2 & 0.1 & 0.3 & 0.0 & 0.1 & 0.0 & 0.0 & 0.0 & 0.0 \\
\hline & $\mathrm{C}$ & B & B & $\mathrm{A}$ & $\mathrm{b}$ & $\mathrm{a}$ & $\mathrm{b}$ & $\mathrm{a}$ & B & A & B & A & b & a & $\mathbf{b}$ & a \\
\hline \multirow{4}{*}{$\begin{array}{l}\text { Flavo-noids, } \\
\text { mg/mg FW }\end{array}$} & 15.1 & 18.7 & 30.7 & 41.9 & 25.5 & 28.3 & 23.0 & 31.4 & 20.6 & 27.4 & 18.9 & 23.6 & 31.4 & 31.1 & 23.9 & 32.6 \\
\hline & \pm & \pm & \pm & \pm & \pm & \pm & \pm & \pm & \pm & \pm & \pm & \pm & \pm & \pm & \pm & \pm \\
\hline & 0.9 & 1.9 & 2.1 & 1.8 & 0.7 & 2.3 & 1.2 & 1.9 & 1.1 & 2.7 & 1.4 & 0.9 & 2.0 & $\overrightarrow{1.1}$ & 2.2 & 2.5 \\
\hline & $\mathrm{D}$ & $\mathrm{C}$ & B & A & $a b$ & $\mathrm{a}$ & $\mathrm{b}$ & $\mathrm{a}$ & C & A & C & B & $\mathbf{a}$ & $\mathbf{a}$ & $\mathbf{b}$ & a \\
\hline
\end{tabular}

Different letters for each plant species indicate significant differences between the mean values at $p<0.05$.

\subsection{Anthocyanins and Flavonoids}

In all, CL-treated microgreens anthocyanins and flavonoids contents were significantly increased (Table 2), except for FLU-CL radish plants. The highest level of anthocyanins and flavonoids contents in arugula and broccoli were detected in LED-CL plants. Higher anthocyanins and other flavonoids contents were correlated with visible purple and blue coloration of abaxial leaf sell layers.

\subsection{Leaf Oxidative Stress and Antioxidative Enzyme Activity}

The results indicate that all microgreens grown under $\mathrm{CL}$ had higher $\mathrm{H}_{2} \mathrm{O}_{2}$ content compared to control plants. In arugula, a $54 \%$ increase in $\mathrm{H}_{2} \mathrm{O}_{2}$ content was observed only in LED-CL plants, while mizuna had 2.5 times and $25 \%$ higher $\mathrm{H}_{2} \mathrm{O}_{2}$ content in FLU-CL and LED-CL treatment, correspondingly. 
There were some differences in plant response induced by CL between microgreen species in respect to the level of lipid peroxidation determined in terms of malondyaldehyd (MDA) content and antioxidant enzyme activities. In arugula and broccoli, CL significantly increased the lipid peroxidation (Table 3) and effects were stronger in LED treatments. In mizuna and radish, CL treatments did not increase MDA content under neither of the two light qualities. The activities of antioxidant enzymes-catalase (CAT), superoxide dismutase (SOD), ascorbate peroxidase (APX), and guaiacol peroxidase (GPX) were increased by CL treatments to different extent, but the most dramatic increases were recorded for SOD activity in CL-grown broccoli and mizuna plants.

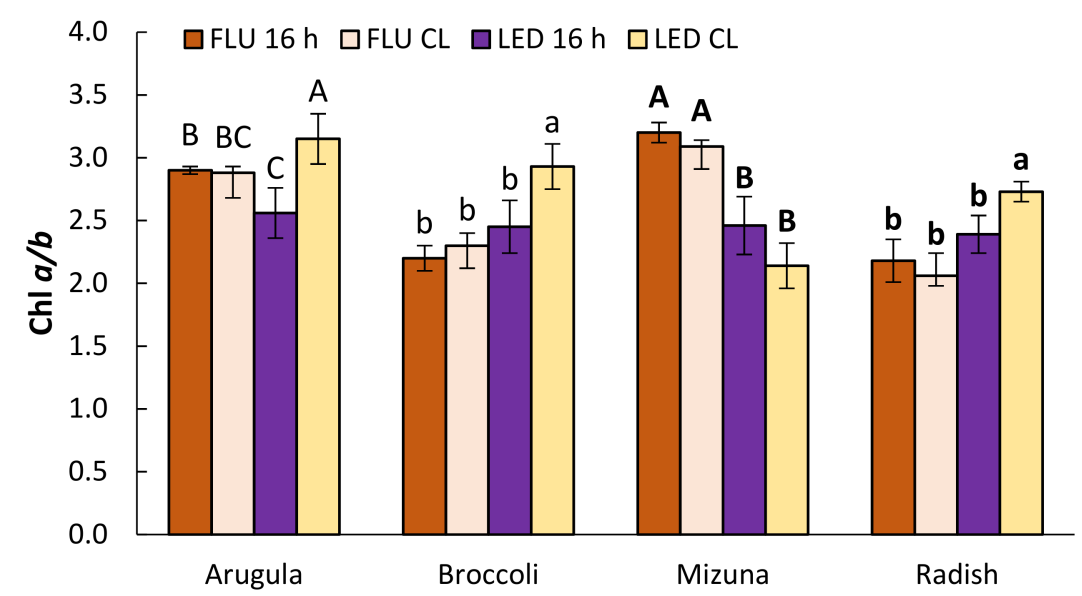

Figure 2. Chl $a / b$ ratio of arugula, broccoli, mizuna, and radish microgreens grown under $16 \mathrm{~h}$ photoperiod or CL provided by fluorescent (FLU) or LED lamps. The results are presented as the mean \pm standard error. Different letters for each parameter and plant species indicate significant differences between the mean values at $p<0.05$.

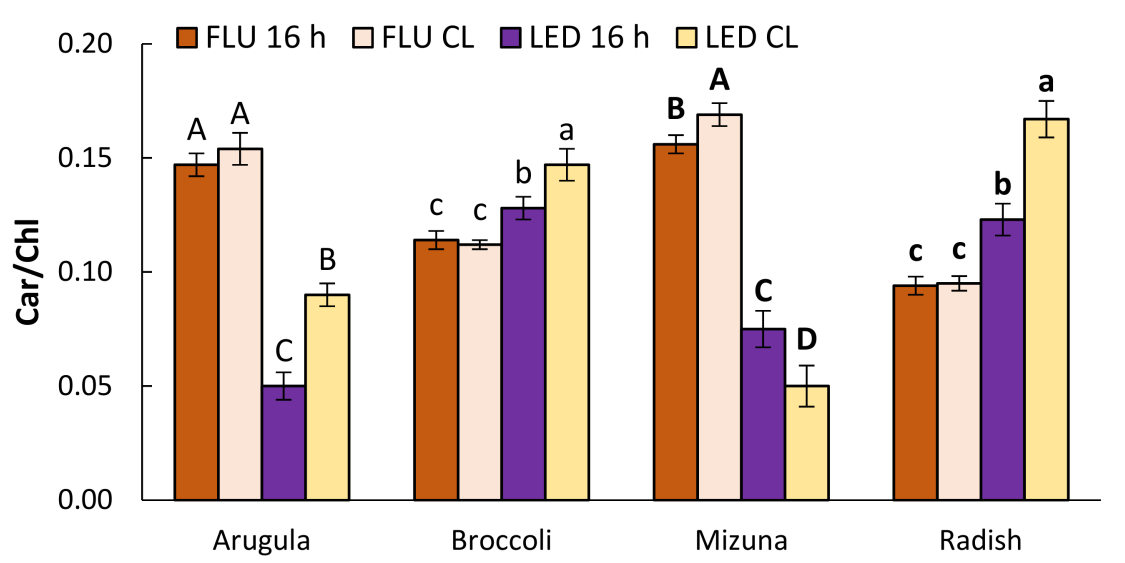

Figure 3. The ratio of carotenoid to chlorophyll content of arugula, broccoli, mizuna, and radish microgreens grown under $16 \mathrm{~h}$ photoperiod or CL provided by fluorescent (FLI) or LED lamps. The results are presented as the mean \pm standard error. Different letters for each parameter and plant species indicate significant differences between the mean values at $p<0.05$.

CL did not induce significant increase in the membrane permeability estimated through a relative electrolyte leakage (REL) from the cotyledon tissues in all plant species (Table 3).

Higher proline content was observed in CL-treated plants (Table 3), except for FLUCL-treated mizuna plants. 
Table 3. The malondialdehyde (MDA), $\mathrm{H}_{2} \mathrm{O}_{2}$, proline content, relative electrolyte leakage (REL) and catalase (CAT), superoxide dismutase (SOD), ascorbate peroxidase (APX), and guaiacol peroxidase (GPX) enzyme activities of microgreens grown under $16 \mathrm{~h}$ photoperiod or continuous light provided by fluorescent (FLU) lamps or LEDs.

\begin{tabular}{|c|c|c|c|c|c|c|c|c|c|c|c|c|c|c|c|c|}
\hline \multirow{3}{*}{ Parameter } & \multicolumn{4}{|c|}{ Arugula } & \multicolumn{4}{|c|}{ Broccoli } & \multicolumn{4}{|c|}{ Mizuna } & \multicolumn{4}{|c|}{ Radish } \\
\hline & \multicolumn{2}{|c|}{ FLU } & \multicolumn{2}{|c|}{ LED } & \multicolumn{2}{|c|}{ FLU } & \multicolumn{2}{|c|}{ LED } & \multicolumn{2}{|c|}{ FLU } & \multicolumn{2}{|c|}{ LED } & \multicolumn{2}{|c|}{ FLU } & \multicolumn{2}{|c|}{ LED } \\
\hline & $16 \mathrm{~h}$ & CL & $16 \mathrm{~h}$ & CL & $16 \mathrm{~h}$ & CL & $16 \mathrm{~h}$ & CL & $16 \mathrm{~h}$ & CL & $16 \mathrm{~h}$ & CL & $16 \mathrm{~h}$ & CL & $16 \mathrm{~h}$ & CL \\
\hline $\begin{array}{c}\text { MDA, } \\
\mu \mathrm{mol} / \mathrm{g} \text { FW }\end{array}$ & $\begin{array}{c}43.2 \\
\pm \\
4.6 \\
C\end{array}$ & $\begin{array}{c}92.4 \\
\pm \\
5.5 \\
\mathrm{~A}\end{array}$ & $\begin{array}{c}20.1 \\
\pm \\
0.7 \\
D\end{array}$ & $\begin{array}{c}55.5 \\
\pm \\
4.2 \\
\mathrm{~B}\end{array}$ & $\begin{array}{c}26.5 \\
\pm \\
2.4 \\
\mathrm{~b}\end{array}$ & $\begin{array}{c}47.9 \\
\pm \\
10.5 \\
\mathrm{a}\end{array}$ & $\begin{array}{c}18.4 \\
\pm \\
1.3 \\
\text { c }\end{array}$ & $\begin{array}{c}60.6 \\
\pm \\
7.6 \\
a\end{array}$ & $\begin{array}{c}14.2 \\
\pm \\
1.2 \\
\mathbf{A}\end{array}$ & $\begin{array}{c}14.2 \\
\pm \\
1.2 \\
\mathbf{A}\end{array}$ & $\begin{array}{c}11.9 \\
\pm \\
0.5 \\
\mathbf{A}\end{array}$ & $\begin{array}{c}13.0 \\
\pm \\
1.1 \\
\mathbf{A}\end{array}$ & $\begin{array}{c}21.8 \\
\pm \\
2.0 \\
\mathbf{a}\end{array}$ & $\begin{array}{c}20.6 \\
\pm \\
1.0 \\
\mathbf{a}\end{array}$ & $\begin{array}{c}18.4 \\
\pm \\
1.3 \\
\mathbf{b}\end{array}$ & $\begin{array}{c}18.0 \\
\pm \\
0.5 \\
\mathbf{b}\end{array}$ \\
\hline $\begin{array}{c}\mathrm{H}_{2} \mathrm{O}_{2} \\
\mu \mathrm{mol} / \mathrm{g} \text { FW }\end{array}$ & $\begin{array}{c}0.93 \\
\pm \\
0.06 \\
\text { A }\end{array}$ & $\begin{array}{c}1.00 \\
\pm \\
0.22 \\
\mathrm{~A}\end{array}$ & $\begin{array}{c}0.54 \\
\pm \\
0.04 \\
C\end{array}$ & $\begin{array}{c}0.83 \\
\pm \\
0.07 \\
B\end{array}$ & $\begin{array}{c}0.61 \\
\pm \\
0.12 \\
b\end{array}$ & $\begin{array}{c}0.87 \\
\pm \\
0.04 \\
a\end{array}$ & $\begin{array}{c}0.71 \\
\pm \\
0.05 \\
b\end{array}$ & $\begin{array}{c}0.93 \\
\pm \\
0.02 \\
\mathrm{a}\end{array}$ & $\begin{array}{c}0.70 \\
\pm \\
0.09 \\
\mathbf{B}\end{array}$ & $\begin{array}{c}1.74 \\
\pm \\
0.13 \\
\mathbf{A}\end{array}$ & $\begin{array}{c}0.63 \\
\pm \\
0.04 \\
\text { C }\end{array}$ & $\begin{array}{c}0.79 \\
\pm \\
0.04 \\
\mathbf{B}\end{array}$ & $\begin{array}{c}0.68 \\
\pm \\
0.02 \\
\mathbf{b}\end{array}$ & $\begin{array}{c}0.84 \\
\pm \\
0.02 \\
\mathbf{a}\end{array}$ & $\begin{array}{c}0.40 \\
\pm \\
0.05 \\
\mathbf{d}\end{array}$ & $\begin{array}{c}0.55 \\
\pm \\
0.04 \\
\text { c }\end{array}$ \\
\hline REL, \% & $\begin{array}{c}8.7 \\
\pm \\
0.6 \\
C\end{array}$ & $\begin{array}{c}9.8 \\
\pm \\
0.8 \\
C\end{array}$ & $\begin{array}{c}17.5 \\
\pm \\
2.0 \\
A\end{array}$ & $\begin{array}{c}14.1 \\
\pm \\
1.4 \\
\mathrm{~B}\end{array}$ & $\begin{array}{c}11.3 \\
\pm \\
0.3 \\
\mathrm{a}\end{array}$ & $\begin{array}{c}12.4 \\
\pm \\
0.6 \\
\mathrm{a}\end{array}$ & $\begin{array}{c}13.7 \\
\pm \\
1.8 \\
\mathrm{a}\end{array}$ & $\begin{array}{c}12.2 \\
\pm \\
1.5 \\
\mathrm{a}\end{array}$ & $\begin{array}{c}5.1 \\
\pm \\
0.4 \\
\text { B }\end{array}$ & $\begin{array}{c}4.6 \\
\pm \\
0.3 \\
\mathbf{B}\end{array}$ & $\begin{array}{c}10.6 \\
\pm \\
0.2 \\
\text { A }\end{array}$ & $\begin{array}{c}8.9 \\
\pm \\
0.5 \\
\text { A }\end{array}$ & $\begin{array}{c}12.1 \\
\pm \\
0.6 \\
\mathbf{a}\end{array}$ & $\begin{array}{c}9.9 \\
\pm \\
0.3 \\
\mathbf{b}\end{array}$ & $\begin{array}{c}12.7 \\
\pm \\
0.5 \\
\mathbf{a}\end{array}$ & $\begin{array}{c}12.7 \\
\pm \\
2.1 \\
\mathbf{a}\end{array}$ \\
\hline $\begin{array}{c}\text { Proline, } \\
\mu \mathrm{mol} / \mathrm{g} \text { FW }\end{array}$ & $\begin{array}{c}40.9 \\
\pm \\
1.1 \\
C\end{array}$ & $\begin{array}{c}49.4 \\
\pm \\
3.9 \\
\text { B }\end{array}$ & $\begin{array}{c}27.4 \\
\pm \\
2.5 \\
D\end{array}$ & $\begin{array}{c}182 \\
\pm \\
21 \\
\mathrm{~A}\end{array}$ & $\begin{array}{c}53.5 \\
\pm \\
4.3 \\
\mathrm{a}\end{array}$ & $\begin{array}{c}58.4 \\
\pm \\
7.5 \\
\mathrm{a}\end{array}$ & $\begin{array}{c}26.5 \\
\pm \\
2.8 \\
\text { C }\end{array}$ & $\begin{array}{c}36.5 \\
\pm \\
3.5 \\
\mathrm{~b}\end{array}$ & $\begin{array}{c}49.5 \\
\pm \\
4.3 \\
\mathbf{B}\end{array}$ & $\begin{array}{c}60.2 \\
\pm \\
2.9 \\
\mathbf{A}\end{array}$ & $\begin{array}{c}11.5 \\
\pm \\
0.3 \\
C\end{array}$ & $\begin{array}{c}12.5 \\
\pm \\
1.2 \\
\text { C }\end{array}$ & $\begin{array}{c}20.8 \\
\pm \\
1.5 \\
\mathbf{b}\end{array}$ & $\begin{array}{c}58.4 \\
\pm \\
0.8 \\
\mathbf{a}\end{array}$ & $\begin{array}{c}7.6 \\
\pm \\
1.3 \\
\text { c }\end{array}$ & $\begin{array}{c}17.1 \\
\pm \\
4.7 \\
\mathbf{b}\end{array}$ \\
\hline $\begin{array}{c}\text { CAT, } \\
\mu \mathrm{mol} /(\mathrm{mg} \\
\text { protein min) }\end{array}$ & $\begin{array}{c}31.1 \\
\pm \\
3.0 \\
C\end{array}$ & $\begin{array}{c}42.2 \\
\pm \\
4.1 \\
\mathrm{~A}\end{array}$ & $\begin{array}{c}39.9 \\
\pm \\
3.2 \\
\mathrm{~B}\end{array}$ & $\begin{array}{c}47.0 \\
\pm \\
1.3 \\
\mathrm{~A}\end{array}$ & $\begin{array}{c}39.3 \\
\pm \\
2.1 \\
\mathrm{~b}\end{array}$ & $\begin{array}{c}55.4 \\
\pm \\
5.0 \\
a\end{array}$ & $\begin{array}{c}32.3 \\
\pm \\
2.6 \\
\mathrm{~b}\end{array}$ & $\begin{array}{c}36.4 \\
\pm \\
3.9 \\
\mathrm{~b}\end{array}$ & $\begin{array}{c}29.3 \\
\pm \\
2.4 \\
\text { D }\end{array}$ & $\begin{array}{c}42.4 \\
\pm \\
3.7 \\
\text { B }\end{array}$ & $\begin{array}{c}38.3 \\
\pm \\
5.5 \\
C\end{array}$ & $\begin{array}{c}49.0 \\
\pm \\
2.1 \\
\mathbf{A}\end{array}$ & $\begin{array}{c}19.1 \\
\pm \\
1.7 \\
\mathbf{b}\end{array}$ & $\begin{array}{c}20.3 \\
\pm \\
1.9 \\
\mathbf{b}\end{array}$ & $\begin{array}{c}10.4 \\
\pm \\
2.8 \\
\mathbf{c}\end{array}$ & $\begin{array}{c}30.1 \\
\pm \\
3.1 \\
\mathbf{a}\end{array}$ \\
\hline $\begin{array}{l}\mathrm{SOD}, \mathrm{U} / \mathrm{mg} \\
\text { protein }\end{array}$ & $\begin{array}{c}32.1 \\
\pm \\
2.8 \\
\mathrm{~A}\end{array}$ & $\begin{array}{c}35.3 \\
\pm \\
2.6 \\
\mathrm{~A}\end{array}$ & $\begin{array}{c}5.0 \\
\pm \\
1.0 \\
\mathrm{C}\end{array}$ & $\begin{array}{c}9.0 \\
\pm \\
1.0 \\
\mathrm{~B}\end{array}$ & $\begin{array}{c}5.6 \\
\pm \\
1.6 \\
c\end{array}$ & $\begin{array}{c}18.4 \\
\pm \\
1.5 \\
\mathrm{a}\end{array}$ & $\begin{array}{c}6.6 \\
\pm \\
1.2 \\
c\end{array}$ & $\begin{array}{c}10.8 \\
\pm \\
0.7 \\
\mathrm{~b}\end{array}$ & $\begin{array}{c}41.0 \\
\pm \\
3.6 \\
\text { B }\end{array}$ & $\begin{array}{c}57.2 \\
\pm \\
6.5 \\
\text { A }\end{array}$ & $\begin{array}{c}13.0 \\
\pm \\
4.0 \\
\mathrm{C}\end{array}$ & $\begin{array}{c}17.0 \\
\pm \\
3.0 \\
\mathrm{C}\end{array}$ & $\begin{array}{c}7.4 \\
\pm \\
1.1 \\
\mathbf{b}\end{array}$ & $\begin{array}{l}9.9 \\
\pm \\
0.6 \\
\mathbf{b}\end{array}$ & $\begin{array}{c}15.3 \\
\pm \\
1.4 \\
\mathbf{a}\end{array}$ & $\begin{array}{c}15.6 \\
\pm \\
1.9 \\
\mathbf{a}\end{array}$ \\
\hline $\begin{array}{c}\text { APX, } \\
\mu \mathrm{mol} /(\mathrm{mg} \\
\text { protein min) }\end{array}$ & $\begin{array}{c}93.2 \\
\pm \\
7.9 \\
\mathrm{~B}\end{array}$ & $\begin{array}{c}125.0 \\
\pm \\
23.2 \\
\mathrm{~A}\end{array}$ & $\begin{array}{c}113.1 \\
\pm \\
16.3 \\
\mathrm{~B}\end{array}$ & $\begin{array}{c}149.3 \\
\pm \\
13.6 \\
\mathrm{~A}\end{array}$ & $\begin{array}{c}78.4 \\
\pm \\
6.1 \\
\mathrm{~b}\end{array}$ & $\begin{array}{c}121.3 \\
\pm \\
12.5 \\
\mathrm{a}\end{array}$ & $\begin{array}{c}79.4 \\
\pm \\
13.3 \\
\mathrm{~b}\end{array}$ & $\begin{array}{c}131.3 \\
\pm \\
24.7 \\
\mathrm{a}\end{array}$ & $\begin{array}{c}95.9 \\
\pm \\
16.3 \\
\mathbf{B}\end{array}$ & $\begin{array}{c}231.0 \\
\pm \\
41.3 \\
\mathbf{A}\end{array}$ & $\begin{array}{c}96.4 \\
\pm \\
23.7 \\
\text { B }\end{array}$ & $\begin{array}{c}114.2 \\
\pm \\
14.1 \\
\mathbf{B}\end{array}$ & $\begin{array}{c}64.4 \\
\pm \\
4.4 \\
\text { c }\end{array}$ & $\begin{array}{c}65.4 \\
\pm \\
12.2 \\
\text { c }\end{array}$ & $\begin{array}{c}143.7 \\
\pm \\
2.9 \\
\mathbf{b}\end{array}$ & $\begin{array}{c}163.2 \\
\pm \\
3.3 \\
\mathbf{a}\end{array}$ \\
\hline $\begin{array}{c}\text { GPX, } \\
\mu \mathrm{mol} /(\mathrm{mg} \\
\text { protein min) }\end{array}$ & $\begin{array}{l}17.0 \\
\pm \\
2.8 \\
\mathrm{~A}\end{array}$ & $\begin{array}{c}18.3 \\
\pm \\
3.7 \\
\mathrm{~A}\end{array}$ & $\begin{array}{c}19.1 \\
\pm \\
2.7 \\
\mathrm{~A}\end{array}$ & $\begin{array}{c}20.3 \\
\pm \\
1.9 \\
\mathrm{~A}\end{array}$ & $\begin{array}{c}205.2 \\
\pm \\
18.2 \\
\mathrm{~b}\end{array}$ & $\begin{array}{c}256.3 \\
\pm \\
20.0 \\
a\end{array}$ & $\begin{array}{c}193.3 \\
\pm \\
31.4 \\
\mathrm{~b}\end{array}$ & $\begin{array}{c}225.7 \\
\pm \\
28.6 \\
\mathrm{a}\end{array}$ & $\begin{array}{c}178.4 \\
\pm \\
21.0 \\
\mathbf{B}\end{array}$ & $\begin{array}{c}348.4 \\
\pm \\
72.9 \\
\mathbf{A}\end{array}$ & $\begin{array}{c}180.4 \\
\pm \\
20.3 \\
\mathbf{B}\end{array}$ & $\begin{array}{c}235.8 \\
\pm \\
71.6 \\
\mathbf{A}\end{array}$ & $\begin{array}{c}113.3 \\
\pm \\
3.9 \\
\mathbf{b}\end{array}$ & $\begin{array}{c}126.2 \\
\pm \\
17.0 \\
\mathbf{a b}\end{array}$ & $\begin{array}{c}141.4 \\
\pm \\
14.8 \\
\mathbf{a}\end{array}$ & $\begin{array}{c}146.2 \\
\pm \\
17.5 \\
\mathbf{a}\end{array}$ \\
\hline
\end{tabular}

Different letters for each plant species indicate significant differences between the mean values at $p<0.05$.

\section{Discussion}

\subsection{Plant Growth and Yield}

In our research, FW, DW, and LMA of all studied species increased in CL-treated plants compared to plants grown under $16 \mathrm{~h}$ photoperiod. This plant response was rather expected as the CL treatments with the higher DLI provided additional light for photosynthetic activity and therefore biomass accumulation. In general, plant DM increases as DLI increases up to a light saturation point [27]. The higher productivity and the implied photosynthetic assimilation rate, measured in our CL treatments, support the hypothesis [19] that the use of CL provides constant energy for carbon assimilation, meaning larger biomass accumulation and yield if no CL-injury occurs. Obtained results show that all four plant species did not develop any symptoms of CL-induced injuries and therefore accumulated more dry mass. Samuoliene et al. [28] also reported similar increases in DW of tatsoi and red pak choi microgreens, as DLI increased. As for the sensitivity of studied plant species to $\mathrm{CL}$, the only available report informs that the efficiency of rocket indoor cultivation was ameliorated by CL without detrimental effects on the yield and quality of edible leaves [18]. A major goal of commercial microgreen producers is to provide growth conditions that maximize as microgreens are sold on a FW basis [29]. In our study, this was the case with all four species in all CL treatments. RI relates individual components of hypocotyl volume (i.e., length and diameter) to DW and serves as a proxy for plant robustness. CL increased RI in all four microgreen species regardless of light spectrum due to decreased HL and increased DW. CL significantly accelerated the emergence of the 
first true leaf. As microgreens are typically harvested at the stage of the first true leaf, CL may serve as a way to reduce the time to harvest. There are numerous reports reviewed by Sysoeva et al. [20] testifying that CL increases developmental rate of plants. Thus, CL can increase yield and/or shorten production time in arugula, broccoli, mizuna, and radish microgreens.

\subsection{Photosynthetic Pigments}

The effects of light on photosynthetic pigment content varies depending on photoperiod $[18,20,30,31]$, the light spectrum applied during plant growth $[13,16,32]$, and plant species [20]. In this study chlorophyll content of broccoli and radish was not significantly influenced by photoperiod (or DLI) or light quality (Table 2). However, Chl content decreased in arugula and mizuna, which was not observed visually. This is important as $\mathrm{Chl}$ content is closely associated with human perception of the green pigmentation of leaves [33]. Total Chl content was also negatively affected when CL provided by RB LEDs was applied to rocket leaves [18]. In all LED-CL plants, we observed a reduction in LHCII, and an elevation of the $\mathrm{Chl} / \mathrm{a} / \mathrm{b}$ ratio (Figure 2 ) and the $\mathrm{Car} / \mathrm{Chl}$ ratio (Figure 3). Decrease in total Chl content in the leaves reduces the light absorption efficiency by photosynthetic apparatus per unit of leaf area and may serve as one of the protection mechanisms against excessive light. An increase in the $\mathrm{Chl} a / b$ ratio suggests that individual PSII complexes developed smaller LHCII during CL. It is considered as characteristic of plant adaptation to high light. The observed an increase in the ratio of yellow to green pigments under $\mathrm{CL}$, which indicates a relatively higher concentration of Car in the pool of photosynthetic pigments, is also associated with their protective function during adaptation to excess lighting [34] as Car play a protective role against ROS as they are known to be very efficient physical and chemical quenchers of singlet oxygen and potent scavengers of other free radicals [35]. Thus, plants under CL either did not have less Chl than plants grown under $16 \mathrm{~h}$ photoperiod, or total $\mathrm{Chl}$ decrease was not that dramatic to decrease overall visual quality of microgreens. At the same time, increased Car content in arugula and radish adds nutritional value to microgreens as Car possess antioxidant properties that are beneficial for human health $[36,37]$.

\subsection{Leaf Oxidative Stress and Antioxidants}

The increased MDA and $\mathrm{H}_{2} \mathrm{O}_{2}$ content in CL-treated plants suggest that CL increased photo-oxidative pressure in plants. In response to stress, plants accumulate antioxidant bioactive compounds. In this study, we recorded the increase in proline, anthocyanin, and flavonoid contents, and elevated activities of antioxidant enzymes (CAT, SOD, APX, and GPX). Higher concentrations of superoxide anion and the $\mathrm{H}_{2} \mathrm{O}_{2}$ concentrations as well as higher activity of CAT, SOD, and APX were also observed in CL-treated tomato plants compared to plants grown under $16 \mathrm{~h}$ photoperiod with the same DLI [38]. Increased content of anthocyanins was also reported for rocket leaves grown under CL provided by cool white LEDs, and by red and blue (RB) LED conditions, with the value doubling in the presence of $\mathrm{RB}$ radiation [18]. The role of antioxidants in scavenging free radicals suggests that they serve as essential compounds for human health, protecting the human organism against ROS [39]. Other results [27,40-46] demonstrate that higher DLI is normally beneficial to growth and nutritional quality of leafy plants. The question arises whether the higher DLI or extended photoperiod itself is a reason of the excess of absorbed light that increases photooxidative pressure and makes plant to produce photoprotective antioxidants. Thus, it was shown that plants may develop CL-induced injury even if DLI is not higher than normally required by plants under shorter photoperiods [47].

Horticultural Brassicaceae plants are valuable source of vitamins, minerals, antioxidants, and dietary fibers [48-50]. In addition, they can be cultivated as microgreens under such lighting conditions that enhance synthesis of antioxidants. The popularity of microgreens as a 'functional' food is gained due to high nutritional quality, and as a culinary ingredient due to their intense color, flavor, and tender texture [39,51]. Thus, CL provided 
by LEDs may add nutritional value to microgreens by increasing the antioxidant properties. These results are consistent with several studies that have reported the benefits of LEDs for nutritional value of horticultural crops reviewed by Loi et al. [13]. Moreover, low nitrate levels can add value to microgreens in the marketplace. The nitrate content is potentially harmful to human health. It was significantly reduced in the rocket leaves grown under CL conditions regardless of the light spectrum applied [18]. However, higher light intensity had little impact on nitrate levels in kale, cabbage and arugula microgreens [52], and mizuna [53]. Other studies have revealed that nitrate levels in lettuce and some microgreens were unaffected by LEDs when varying blue light proportion $[43,54,55]$. These and other findings indicated that additional environmental factors influenced nitrate accumulation [52]. Therefore, more research is required to address the relationship between species genotype, nitrogen supply and uptake, and light conditions, in order to produce microgreens with the lowest nitrate content.

\section{Materials and Methods}

\subsection{Plant Material and Growth Conditions}

Arugula (Eruca vesicaria subsp. sativa (Mill.) Thell.), broccoli (Brassica oleracea var. italica Plenck), mizuna (Brassica rapa. var. nipposinica (L.H.Bailey) Hanelt), and radish (Raphanus sativus var. radicula Pers.) were grown under controlled environmental conditions in a growth chamber (Snijders, The Netherlands). The average air temperature and relative air humidity were $22 \pm 1{ }^{\circ} \mathrm{C}$ and $60 \pm 5 \%$, respectively. No supplemental $\mathrm{CO}_{2}$ was used in the experiment.

Trays $\left(10 \mathrm{~cm}^{2}\right)$ with coconut coir mats without drainage holes were used for microgreen culture. Eight trays were used for each species by sowing 1.8, 3.6, 3.6, and $4.8 \mathrm{~g}$ of arugula, broccoli, mizuna, and radish seeds evenly onto each mat. For the first $3 \mathrm{~d}$ after sowing trays of microgreens were placed to germinate in darkness and were top-irrigated with water. Once cotyledons were fully reflexed on the 4th day after sowing, a half-strength Hoagland's nutrient solution [56] ( $\mathrm{pH}$ 6.2-6.4) was added to each tray daily until harvest.

\subsection{Light Treatments}

Four light treatments were set from the 4th day after sowing until harvest (Table 4): (1) FLU-16h with a photoperiod of $16 \mathrm{~h}$ light $/ 8 \mathrm{~h}$ dark provided by fluorescent lamps (F36W / T8 BRITEGRO, Sylvania, Germany) served as a control for fluorescent light treatment; (2) LED-16h with a photoperiod of $16 \mathrm{~h}$ light $/ 8 \mathrm{~h}$ dark provided by LEDs (LED GL V300, China) served as a control for LED treatment; (3) FLU-CL with a photoperiod of $24 \mathrm{~h}$ continuous light provided by fluorescent lamps; (4) LED-CL with a photoperiod of $24 \mathrm{~h}$ continuous light provided by LEDs. LED light ratio (\%) of red:green:blue was 50.3:21.1:17.6.

Table 4. Light conditions (light source, photoperiod, light intensity, and daily light integral) of treatments.

\begin{tabular}{|c|c|c|c|c|}
\hline Treatments & $\begin{array}{l}\text { Light } \\
\text { Source }\end{array}$ & $\begin{array}{c}\text { Photoperiod, } \\
\text { h }\end{array}$ & 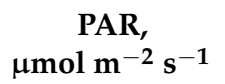 & $\begin{array}{c}\text { DLI, } \\
\text { mol m}^{-2} \text { day }^{-1}\end{array}$ \\
\hline FLU-16 h (control FLU) & FLU & 16 & 270 & 15.6 \\
\hline LED-16 h (control LED) & LED & 16 & 270 & 15.6 \\
\hline FLU-CL & FLU & 24 & 270 & 23.3 \\
\hline LED-CL & LED & 24 & 270 & 23.3 \\
\hline
\end{tabular}

The PPFD of $270 \mu \mathrm{mol} \mathrm{m}^{-2} \mathrm{~s}^{-1}$ was used in all treatments providing daily cumulative intensity of photosynthetically active quanta (as daylight integral, DLI) $15.6 \mathrm{~mol} \mathrm{~m}^{-2}$ day $^{-1}$ and $23.3 \mathrm{~mol} \mathrm{~m}^{-2} \mathrm{day}^{-1}$ for plants grown under $16 \mathrm{~h}$ photoperiod and $\mathrm{CL}$, respectively. The PPFD was measured using LI-250A Light Meter (Li-COR Biosciences, Lincoln, NE, USA). All trays were systematically rearranged every day to minimize disproportion in light distribution. 


\subsection{Growth Measurements}

Microgreens were harvested at the visual appearance of true leaves, resulting in the harvest date of 12 days after sowing.

Ten seedlings of each species were randomly selected and measured to determine hypocotyl length (HL), first true leaf length (LL), fresh weight (FW), and dry weight (DW) for each light treatment. HL was measured from the base of the hypocotyl to the shoot apical meristem. To determine FW seedlings were weighed as quickly as possible to limit the losses through evaporation and then samples were dried at $105^{\circ} \mathrm{C}$ in an oven until a constant dry weight (DW) was observed. FW and DW data were then used to report water content (WC, \%). The values of leaf mass per area (LMA) were calculated as a ratio of a dry mass of the lamina discs to their area. Eight discs were cut from cotyledons with a 4-mm in diameter cork borer. The dry weight of the discs was determined after their drying to a constant weight at $105^{\circ} \mathrm{C}$.

Robust index $(\mathrm{RI})=$ Hypocotyl diameter $(\mathrm{HD}) /$ Hypocotyl length $(\mathrm{HL}) \times$ Dry weight (DW) [57]

\subsection{Photosynthetic Pigment Content Measurement}

Five plants per treatment were randomly selected for the following measurements. Content of $\mathrm{Chl} a$ and $b$ and carotenoids (Car) was measured in 96\% ethanol extracts with a SF2000 spectrophotometer (Spectrum, Russia) and calculated according to the known formulas [58]. The percentage of $\mathrm{Chl}$ in light harvesting complex II (LHCII) was calculated by accepting that almost all $\mathrm{Chl} b$ is in LHCII, and that the ratio of Chl $a$ and $b$ in LHCII is 1.2 [59].

\subsection{Measurement of Lipid Peroxidation Levels}

The content of MDA, the end product of lipid peroxidation, was determined with a standard method based on the reaction of these substances with thiobarbituric acid (TBA) that produces a trimethine complex [60]. Leaf sample $(0.1 \mathrm{~g})$ was homogenized in $2 \mathrm{~mL}$ of $50 \mathrm{mM}$ phosphate buffer ( $\mathrm{pH} 7.0$ ). The homogenate was centrifuged at $15,000 \times g$ for $15 \mathrm{~min}$. To $1.0 \mathrm{~mL}$ aliquot of the supernatant, $2.0 \mathrm{~mL}$ of $0.5 \%$ TBA in $20 \%$ trichloroacetic acid was added. The mixture was heated at $95{ }^{\circ} \mathrm{C}$ for $30 \mathrm{~min}$ on the water bath and then cooled in an ice bath. After centrifugation at $10,000 \times g$ for $10 \mathrm{~min}$ the absorbance of the supernatant was recorded at $532 \mathrm{~nm}$. The value for nonspecific absorption of each sample at $600 \mathrm{~nm}$ was also recorded and subtracted from the absorbance recorded at $532 \mathrm{~nm}$. The concentration of MDA was calculated using an extinction coefficient of $155 \mathrm{mM}^{-1} \mathrm{~cm}^{-1}$. The lipid peroxidation levels were expressed as micromoles of MDA per gram of FW.

\subsection{Antioxidative Enzyme Activity Assays}

For protein and antioxidant enzyme assays, leaf tissues $(0.1 \mathrm{~g})$ were ground in $4 \mathrm{~mL}$ of $50 \mathrm{mM}$ potassium phosphate buffer ( $\mathrm{pH}$ 7.8) using a chilled pestle and mortar. The extraction buffer contained $0.1 \mathrm{mM}$ EDTA and $1 \%(w / v)$ polyvinylpyrrolidone. The homogenate was centrifuged at $14,000 \times \mathrm{g}$ for $20 \mathrm{~min}$ at $4{ }^{\circ} \mathrm{C}$, and the supernatants thus collected were used for the assays of catalase (CAT, EC 1.11.1.6), superoxide dismutase (SOD, EC 1.15.1.1), ascorbate peroxidase (APX, EC 1.11.1.11), and guaiacol peroxidase (GPX, EC 1.11.1.7), and protein determinations.

CAT activity was determined using spectrophotometer SF-2000 (OKB Spectr, Russia) by measuring the rate of $\mathrm{H}_{2} \mathrm{O}_{2}$ disappearance at $240 \mathrm{~nm}$ [61]. The reaction mixture contained $50 \mathrm{mM}$ potassium phosphate buffer ( $\mathrm{pH} 7.0$ ) and $10.5 \mathrm{mM} \mathrm{H}_{2} \mathrm{O}_{2}$. The reaction was run at $25{ }^{\circ} \mathrm{C}$ for $1 \mathrm{~min}$, after adding the enzyme extract and rate of decrease in absorbance at $240 \mathrm{~nm}\left(\mathrm{E}=39.4 \mathrm{mM}^{-1} \mathrm{~cm}^{-1}\right)$ was used to calculate the enzyme activity. CAT activity was expressed in $\mu \mathrm{mol} \mathrm{H}_{2} \mathrm{O}_{2}$ per minute per mg of protein.

SOD activity assay was based on the measurement of inhibition in the photochemical reduction in nitroblue tetrazolium (NBT) spectrophotometrically. The reaction mixture contained 50 mM K-phosphate buffer (pH 7.8), 13 mM methionine, $75 \mu \mathrm{M}$ NBT, $0.1 \mu \mathrm{M}$ 
EDTA, $4 \mu \mathrm{M}$ riboflavin, and the required amount of enzyme extract. The reaction was triggered by adding riboflavin and placing the tubes under fluorescent lamps for $30 \mathrm{~min}$. A complete reaction mixture without enzyme served as control. A non-irradiated complete reaction mixture served as a blank. One unit of SOD activity was defined as the amount of enzyme required to cause $50 \%$ inhibition of the reduction in NBT as monitored at $560 \mathrm{~nm}$ according to [62].

APX was assayed by the method described by Nakano, Asada [63]. The reaction mixture contained $50 \mathrm{mM}$ potassium phosphate buffer ( $\mathrm{pH}$ 7.0), $0.2 \mathrm{mM}$ EDTA, $0.5 \mathrm{mM}$ ascorbic acid, and $0.25 \mathrm{mM} \mathrm{H}_{2} \mathrm{O}_{2}$. The reaction was triggered by the addition of $\mathrm{H}_{2} \mathrm{O}_{2}$ after adding the enzyme extract. The decrease in absorbance at $290 \mathrm{~nm}$ for $1 \mathrm{~min}$ was recorded and the amount of APX was calculated from the extinction coefficient $2.8 \mathrm{mM}^{-1} \mathrm{~cm}^{-1}$.

The activity of GPX was determined spectrophotometrically by measuring the increase in absorbance at $470 \mathrm{~nm}$ [64]. The reaction mixture contained $80 \mathrm{mmol} / \mathrm{L}$ guaiacol and $10 \mathrm{mmol} / \mathrm{L} \mathrm{H}_{2} \mathrm{O}_{2}$ in $0.066 \mathrm{~mol} / \mathrm{L}$ phosphate buffer $(\mathrm{pH}=7.4)$. The enzymatic reaction was started by adding $0.05 \mathrm{~mL}$ of the extract to $2 \mathrm{~mL}$ of reaction mixture. The SOD, APX, and GPX activity values are expressed as unit $\mathrm{U} \mathrm{mg}^{-1}$ protein.

The concentration of protein was determined according to Bradford [65] using bovine serum albumin (BSA) (Dia-M, Russia) as a standard.

\subsection{Measurement of Relative Electrolyte Leakage (REL)}

REL from the cotyledon tissues was determined to estimate the membrane permeability. Ten $4 \mathrm{~mm}$ in diameter leaf discs were rinsed with distilled water, blotted with filter paper, and placed into $10 \mathrm{~mL}$ test tubes with distilled water. After $2 \mathrm{~h}$ shaking at $23{ }^{\circ} \mathrm{C}$, the electric conductivity of the solution (E1) was measured by a conductometer (Ekspert-002, Ekoniks-Ekspert, Russia) at the same temperature. Then, the test tubes were heated until boiling, cooled to room temperature, and the full electrolyte leakage (E2) was evaluated. REL was calculated as a percentage of the full leakage by the formula REL $=100 \times \mathrm{E} 1 / \mathrm{E} 2 \%$.

\subsection{Hydrogen Peroxide Content}

Hydrogen peroxide content was determined according to Velikova et al. [66]. Leaf tissues $(0.1 \mathrm{~g})$ were homogenized in ice bath with $5 \mathrm{~mL} 0.1 \%(w / v)$ TCA. The homogenate was centrifuged at $12,000 \times g$ for $15 \mathrm{~min}$ at $4{ }^{\circ} \mathrm{C}$ and $0.5 \mathrm{~mL}$ of supernatant was added to $0.5 \mathrm{~mL}$ potassium phosphate buffer ( $\mathrm{pH} 7.0$ ) and $1 \mathrm{~mL} 1 \mathrm{M}$ KI. The absorbance of supernatant was measured at $390 \mathrm{~nm}$. The content of $\mathrm{H}_{2} \mathrm{O}_{2}$ was calculated by comparison with a standard calibration curve.

\subsection{Proline}

Free proline content in the leaf tissues was estimated according to Bates et al. [67]. Fresh leaf samples $(0.3 \mathrm{~g})$ were homogenized in $6 \mathrm{~mL}$ of $3 \%$ sulfosalicylic acid and the homogenate was centrifuged at $5100 \times g$ for $5 \mathrm{~min}$. Then, $2 \mathrm{~mL}$ of the supernatant was mixed with $2 \mathrm{~mL}$ freshly prepared ninhydrin reagent $(0.5 \mathrm{~g}$ ninhydrin in $50 \mathrm{~mL}$ of $60 \%$ acetic acid). The colour reaction developed after incubation of the samples for $1 \mathrm{~h}$ in a boiling water bath. After warming to $25^{\circ} \mathrm{C}$, the absorbance was measured at $520 \mathrm{~nm}$. The concentration of proline was estimated by referring to a standard curve of L-proline and expressed in $\mu \mathrm{mol} \mathrm{g}^{-1} \mathrm{FW}$.

\subsection{Anthocyanins and Flavonoids}

Anthocyanins were extracted from leaves according to Kang et al. [68]. Fresh leaves tissues $(0.1 \mathrm{~g})$ were homogenized in $2 \mathrm{~mL}$ of 95\% ethanol-1.5 N HCl- (85:15, v:v). After overnight extraction at $4{ }^{\circ} \mathrm{C}$ in darkness, each sample was centrifuged at $10,000 \times g$ for $5 \mathrm{~min}$. The absorbance of the supernatant was measured at $533 \mathrm{~nm}$ (peak of absorption of anthocyanin) and $657 \mathrm{~nm}$ (peak of absorption of Chl degradation products). The results were plotted as a difference in absorption at 530 and $657 \mathrm{~nm}$ relative to tissue fresh weight 
$\left(\triangle \mathrm{A} \cdot \mathrm{g}^{-1} \mathrm{FW}\right)$ and the formula $\Delta \mathrm{A}=\mathrm{A} 530-1 / 4 \mathrm{~A} 657$ was used to deduct the absorbance contributed by chlorophyll and its degradation products in the extract [69].

The relative amounts of flavonoids were measured spectrophotometrically [70-72]. The supernatant for anthocyanins was diluted 10 times and the absorbance was measured at $300 \mathrm{~nm}$. Flavonoids content in the sample was expressed as absorbance at $530 \mathrm{~nm} \mathrm{~g}^{-1}$ fresh weight of tissue.

\subsection{Data Analysis}

The experiment was performed twice overtime for each species and data were pooled across replications. The figures show mean values and standard errors. Significant differences between the means were revealed at $p<0.05$ using one-way ANOVA analysis (the least significant difference test).

\section{Conclusions}

This study investigated the responses of four microgreen genotypes to CL provided by florescent lights and RB LEDs with PPFD of $270 \mu \mathrm{mol} \mathrm{m} \mathrm{m}^{-2} \mathrm{~s}^{-1}$. Combining results in growth, yield, and nutritional quality of arugula, broccoli, mizuna, and radish microgreens, we suggest that $\mathrm{CL}$ had a significant impact on microgreen growth and nutritional quality. In most cases effects were more pronounced under LED lighting. LED-CL resulted in higher yield and RI compared to shorter photoperiod, and led to increased content of phytochemicals with antioxidative properties (carotenoids, anthocyanins, flavonoids, proline, and antioxidant enzymes). This added nutritional value to microgreens that are used as functional foods providing health benefits.

Author Contributions: Conceptualization, T.G.S.; methodology, T.G.S. and E.G.S.; formal analysis, investigation, T.G.S., E.G.S. and A.A.R.; data curation, T.G.S., E.G.S. and A.A.R.; writing-original draft preparation, T.G.S.; writing-review and editing, T.G.S., E.G.S., A.A.R. and A.F.T.; funding acquisition, T.G.S. and A.F.T. All authors have read and agreed to the published version of the manuscript.

Funding: Support for this study was provided by: RFBR, grant number 20-016-00033a; the state order № FMEN-2022-0004.

Institutional Review Board Statement: Not applicable.

Informed Consent Statement: Not applicable.

Acknowledgments: This research was carried out using the equipment of the Core Facility of the Karelian Research Center of the Russian Academy of Science.

Conflicts of Interest: The authors declare no conflict of interest.

\section{References}

1. Xiao, Z.; Lester, G.E.; Luo, Y.; Wang, Q. Assessment of vitamin and carotenoid concentrations of emerging food products: Edible microgreens. J. Agric. Food Chem. 2012, 60, 7644-7651. [CrossRef]

2. Renna, M.; Montesano, F.F.; Serio, F.; Gonnella, M. Chapter 5-The Mediterranean diet between traditional foods and human health through culinary examples. In Gastronomy and Food Science; Galanakis, C.M., Ed.; Academic Press: Cambridge, MA, USA, 2021; pp. 75-99.

3. Treadwell, D.D.; Hochmuth, R.; Landrum, L.; Laughlin, W. Microgreens: A new specialty crop. IFAS Ext. 2020, HS1164. [CrossRef]

4. Jones-Baumgardt, C.; Llewellyn, D.; Zheng, Y. Different microgreen genotypes have unique growth and yield responses to intensity of supplemental PAR from light-emitting diodes during winter greenhouse production in Southern Ontario, Canada. HortScience 2020, 55, 156-163. [CrossRef]

5. Xiao, Z.; Codling, E.E.; Luo, Y.; Nou, X.; Lester, G.E.; Wang, Q. Microgreens of Brassicaceae: Mineral composition and content of 30 varieties. J. Food Compos. Anal. 2016, 49, 87-93. [CrossRef]

6. Mir, S.A.; Shah, M.A.; Mir, M.M. Microgreens: Production, shelf life, and bioactive components. Crit. Rev. Food Sci. Nutr. 2017, 57, 2730-2736. [CrossRef]

7. Despommier, D. The Vertical Farm: Feeding the World in the 21st Century; Thomas Dunne Books: New York, NY, USA, 2010.

8. Kozai, T.; Nui, G.; Takagaki, M. Plant Factory: An Indoor Vertical Farming System for Efficient Quality Food Production; Academic Press: Cambridge, MA, USA, 2015; p. 516.

9. Despommier, D. Farming up the city: The rise of urban vertical farms. Trends Biotechnol. 2013, 31, 388-389. [CrossRef] [PubMed] 
10. Touliatos, D.; Dodd, I.C.; McAinsh, M. Vertical farming increases lettuce yield per unit area compared to conventional horizontal hydroponics. Food Energy Secur. 2016, 5, 184-191. [CrossRef] [PubMed]

11. Kozai, T.; Niu, G. Role of the plant factory with artificial lighting (PFAL) in urban areas. In Plant Factory: An Indoor Vertical Farming System for Efficient Quality Food Production; Kozai, T., Niu, G., Takagaki, M., Eds.; Academic Press: London, UK, 2020; pp. 7-33.

12. Gerovac, J.R.; Craver, J.K.; Boldt, J.K.; Lopez, R.G. Light intensity and quality from sole-source light-emitting diodes impact growth, morphology, and nutrient content of Brassica microgreens. HortScience 2016, 51, 497-503. [CrossRef]

13. Loi, M.; Villani, A.; Paciolla, F.; Mulè, G.; Paciolla, C. Challenges and Opportunities of Light-Emitting Diode (LED) as Key to Modulate Antioxidant Compounds in Plants. A Review. Antioxidants 2021, 10, 42. [CrossRef] [PubMed]

14. Singh, D.; Basu, C.; Meinhardt-Wollweber, M.; Roth, B. LEDs for energy efficient greenhouse lighting. Renew. Sustain. Energy Rev. 2015, 49, 139-147. [CrossRef]

15. Bantis, F.; Smirnakou, S.; Ouzounis, T.; Koukounaras, A.; Ntagkas, N.; Radoglou, K. Current status and recent achievements in the field of horticulture with the use of light-emitting diodes (LEDs). Sci. Hortic. 2018, 235, 437-451. [CrossRef]

16. Mastropasqua, L.; Dipierro, N.; Paciolla, C. Effects of Darkness and Light Spectra on Nutrients and Pigments in Radish, Soybean, Mung Bean and Pumpkin Sprouts. Antioxidants 2020, 9, 558. [CrossRef] [PubMed]

17. Paradiso, R.; Proietti, S. Light-quality manipulation to control plant growth and photomorphogenesis in greenhouse horticulture: The state of the art and the opportunities of modern led systems. J. Plant Growth Regul. 2021, 21, 1-39. [CrossRef]

18. Proietti, S.; Moscatello, S.; Riccio, F.; Downey, P.; Battistelli, A. Continuous lighting promotes plant growth, light conversion efficiency, and nutritional quality of Eruca vesicaria (L.) Cav. in controlled environment with minor effects due to light quality. Front. Plant Sci. 2021, 12, 730119. [CrossRef] [PubMed]

19. Velez-Ramirez, A.I.; Heuvelink, E.; van Ieperen, W.; Vreugdenhil, D.; Millenaar, F. Continuous light as a way to increase greenhouse tomato production: Expected challenges. ISHS Acta Hortic. 2012, 956, 51-57. [CrossRef]

20. Sysoeva, M.I.; Markovskaya, E.F.; Shibaeva, T.G. Plants under continuous light: A review. Plant Stress 2010, 4, 5-17.

21. Velez-Ramirez, A.I.; van Ieperen, W.; Vreugdenhil, D.; Millenaar, F.F. Plants under continuous light. Trends Plant Sci. 2011, 16, 310. [CrossRef]

22. Haque, M.S.; Kjaer, K.H.; Rosenqvist, E.; Ottosen, C.O. Continuous light increases growth, daily carbon gain, antioxidants, and alters carbohydrate metabolism in a cultivated and a wild tomato species. Front. Plant Sci. 2015, 6, 522. [CrossRef]

23. Zhou, W.; Wenke, L.; Qichang, Y. Reducing nitrate content in lettuce by pre-harvest contibuous light delivered by red and blue light-emitting diodes. J. Plant Nutr. 2013, 36, 481.

24. Bian, Z.-H.; Cheng, R.-F.; Yang, Q.-C.; Wang, J.; Lu, C. Continuous light from red, blue, and green light-emitting diodes reduces nitrate content and enhances phytochemical concentrations and antioxidant capacity in lettuce. J. Am. Soc. Hortic. Sci. 2016, 141, 186. [CrossRef]

25. Ohtake, N.; Ishikura, M.; Suzuki, H. Continuous irradiation with alternating red and blue light enhances plant growth while keeping nutritional quality in lettuce. HortScience 2018, 53, 1804. [CrossRef]

26. Liu, W.; Zha, L.; Zhang, Y. Growth and nutrient element content of hydroponic lettuce are modified by LED continuous lighting of different intensities and spectral qualities. Agronomy 2020, 10, 1678. [CrossRef]

27. Poorter, H.; Niinemets, U.; Ntagkas, N.; Siebenk, A.; Maenpaa, M.; Matsubara, S.; Pons, T.L. A meta-analysis of plant responses to light intensity for 70 traits ranging from molecules to whole plant performance. New Phytol. 2019, 223, 1073-1105. [CrossRef] [PubMed]

28. Samuoliene, G.; Brazaityte, A.; Jankauskiene, J.; Virsile, A.; Sirtautas, R.; Novickovas, A.; Sakalauskiene, S.; Sakalauskaite, J.; Duchovskis, P. LED irradiance level affects growth and nutritional quality of Brassica microgreen. Cent. Eur. J. Biol. 2013, 8, 1241-1249. [CrossRef]

29. Murphy, C.J.; Pill, W.G. Cultural practices to speed the growth of microgreen arugula (roquette; Eruca vesicaria subsp. sativa). J. Hortic. Sci. Biotechnol. 2010, 85, 171-176. [CrossRef]

30. Lefsrud, M.G.; Kopsell, D.A.; Auge, R.M.; Both, A.J. Biomass production and pigment accumulation in kale grown under increasing photoperiods. Hortic. Sci. 2006, 41, 603-606. [CrossRef]

31. Stutte, G.W.; Edney, S.; Skerritt, T. Photoregulation of bioprotectant content of red leaf lettuce with light-emitting diodes. HortScience 2009, 44, 79-82. [CrossRef]

32. Kopsell, D.A.; Sams, C.E.; Morrow, R.C. Interaction of light quality and fertility on biomass, shoot pigmentation and xanthophyll cycle flux in Chinese kale. J. Sci. Food Agric. 2017, 97, 911-917. [CrossRef] [PubMed]

33. Barrett, D.M.; Beaulieu, J.C.; Shewfelt, R. Color, flavor, texture and nutritional quality of fresh-cut fruits and vegetables: Desirable levels, instrumental and sensory measurement, and the effects of processing. Crit. Rev. Food Sci. Nutr. 2010, 50, 369-389. [CrossRef] [PubMed]

34. Demmig-Adams, B.; Adams, W.W., III. Photoprotection and other responses of plants to high light stress. Annu. Rev. Plant Physiol. Plant Mol. Biol. 1992, 43, 599. [CrossRef]

35. Llorente, B.; Martínez-García, J.; Stange, C.; Rodríguez-Concepción, M. Illuminating colors: Regulation of carotenoid biosynthesis and accumulation by light. Curr. Opin. Plant Biol. 2017, 37, 49-55. [CrossRef]

36. Rodriguez-Amaya, D.B. Carotenes and xanthophylls as antioxidants. In Handbook of Antioxidants for Food Preservation; Shahidi, F., Ed.; Woodhead Publishing: Cambridge, UK, 2015; pp. 17-50. 
37. Eggersdorfer, M.; Wyss, A. Carotenoids in human nutrition and health. Arch. Biochem. Biophys. 2018, 652, 18-26. [CrossRef] [PubMed]

38. Hague, M.; de Sousa, A.; Soares, C.; Kjaer, K.H.; Fidalgo, F.; Rosenqvist, E.; Ottosen, C.-O. Temperature variation under continuous light restores tomato leaf photosynthesis and maintains the diurnal pattern in stomatal conductance. Front. Plant Sci. $2017,8,1602$. [CrossRef] [PubMed]

39. Pinto, E.; Almeida, A.A.; Aguiar, A.A.; Ferreira, I.M.P.L.V.O. Comparison between the mineral profile and nitrate content of microgreens and mature lettuces. J. Food Compos. Anal. 2015, 37, 38-43. [CrossRef]

40. Proietti, S.; Moscatello, S.; Leccese, A.; Colla, G.; Battistelli, A. The effect of growing spinach (Spinacia oleracea L.) at low light intensities on the amounts of oxalate, ascorbate and nitrate in their leaves. J. Hortic. Sci. Biotechnol. 2004, 79, 606-609. [CrossRef]

41. Matsuda, R.; Ohashi-Kaneko, K.; Fujiwara, K.; Kurata, K. Effects of blue light deficiency on acclimation of light energy partitioning in PSII and CO2assimilation capacity to high irradiance in spinach leaves. Plant Cell Physiol. 2008, 49, 664-670. [CrossRef] [PubMed]

42. Gent, M.P. Effect of irradiance and temperature on composition of spinach. HortScience 2016, 51, 133-140. [CrossRef]

43. Zhang, T.; Shi, Y.; Piao, F.; Sun, Z. Effects of different LED sources on the growth and nitrogen metabolism of lettuce. Plant Cell Tissue Organ Cult. 2018, 134, 231-240. [CrossRef]

44. Dou, H.; Niu, G.; Gu, M.; Masabni, J.G. Responses of sweet basil to different daily light integrals in photosynthesis, morphology, yield, and nutritional quality. HortScience 2018, 53, 496-503. [CrossRef]

45. Yan, Z.; He, D.; Niu, G.; Zhou, Q.; Qu, Y. Growth, nutritional quality, and energy use efficiency of hydroponic lettuce as influenced by daily light integrals exposed to white versus white plus red light-emitting diodes. HortScience 2019, 54, 1737-1744. [CrossRef]

46. Gao, W.; He, D.; Ji, F.; Zhang, S.; Zheng, J. Effects of daily light integral and LED spectrum on growth and nutritional quality of hydroponic spinach. Agronomy 2020, 10, 1082. [CrossRef]

47. Shibaeva, T.G.; Mamaev, A.V.; Sherudilo, E.G.; Titov, A.F. The role of photosynthetic daily light integral in plant response to extended photoperiods. Russ. J. Plant Physiol. 2022, 69. in press.

48. Björkman, M.; Klingen, I.; Birch, A.N.E.; Bones, A.M.; Bruce, T.J.A.; Johansen, T.J.; Meadow, R.; Mølmann, J.; Seljåsen, R.; Smart, L.E.; et al. Phytochemicals of Brassicaceae in plant protection and human health—influences of climate, environment and agronomic practice. Phytochemistry 2011, 72, 538-556. [CrossRef] [PubMed]

49. Vale, A.; Cidade, H.; Pinto, M.; Oliveira, M. Effect of sprouting and light cycle on antioxidant activity of Brassica oleracea varieties. Food Chem. 2014, 165, 379-387. [CrossRef] [PubMed]

50. Brazaitytè, A.; Viršilè, A.; Jankauskienè, J.; Sakalauskienė, S.; Samuolienè, G.; Sirtautas, R.; Novickovas, A.; Dabasinskas, L.; Miliauskiene, J.; Vastakaite, V.; et al. Effect of supplemental UV-A radiation in solid-state lighting on the growth and phytochemical content of microgreens. Int. Agrophys. 2015, 29, 13-22. [CrossRef]

51. Brazaitytè, A.; Virsilè, A.; Samuolienè, G.; Jankauskienè, J.; Sakalauskienè, S.; Sirtautas, R.; Novičkovas, A.; Dabasinskas, L.; Vastakaitè, V.; Miliauskienè, J.; et al. Light quality: Growth and nutritional value of microgreens under indoor and greenhouse conditions. Acta Hortic. 2016, 1134, 277-284. [CrossRef]

52. Jones-Baumgardt, C.; Llewellyn, D.; Ying, Q.; Zheng, Y. Intensity of sole-source light-emitting diodes affects growth, yield, and quality of Brassicaceae microgreens. HortScience 2019, 54, 1168-1174. [CrossRef]

53. Trejo-Tellez, L.I.; Estrada-Ortiz, E.; Gomez-Merino, F.C.; Becker, C.; Krumbein, A.; Schwarz, D. Flavonoid, nitrate and glucosinolate concentrations in Brassica species are differentially affected by photosynthetically active radiation, phosphate and phosphite. Front Plant Sci. 2019, 10, 371. [CrossRef]

54. Lin, K.-H.; Huang, M.-Y.; Huang, W.-D.; Hsu, M.-H.; Yang, Z.-W.; Yang, C.-M. The effects of red, blue, and white light-emitting diodes on the growth, development, and edible quality of hydroponically grown lettuce (Lactuca sativa L. var. capitata). Sci. Hortic. 2013, 150, 86-91. [CrossRef]

55. Ying, Q.; Jones-Baumgardt, C.; Zheng, Y.; Bozzo, G. The Proportion of blue light from light-emitting diodes alters microgreen phytochemical profiles in a species-specific manner. HortScience 2021, 56, 13-20. [CrossRef]

56. Hoagland, D.R.; Arnon, D.I. The water-culture method for growing plants without soil. Calif. Agric. Exp. Stn. 1950, $347,32$.

57. Fan, X.-X.; Xu, Z.-G.; Liu, X.-Y.; Tang, C.-M.; Wang, L.-W.; Han, X.-L. Effects of light intensity on the growth and leaf development of young tomato plants grown under a combination of red and blue light. Sci. Hortic. 2013, 153, 50-55. [CrossRef]

58. Lichtenthaler, H.K.; Wellburn, A.R. Determinations of total carotenoids and chlorophylls a and b of leaf extracts in different solvents. Biochem. Soc. Trans. 1983, 603, 591-592. [CrossRef]

59. Lichtenthaler, H.K. Chlorophylls and carotenoids: Pigments of photosynthetic biomembranes. Methods Enzymol. 1987, 148, 350-382.

60. Heath, R.L.; Packer, L. Photoperoxidation in isolated chloroplasts. I. Kinetics and stoichiometry of fatty acid peroxidation. Arch Biochem. Biophys. 1968, 125, 189-198. [CrossRef]

61. Aebi, H. Catalase in vitro. Merhods Enzymol. 1984, 105, 121-126.

62. Giannopolitis, C.N.; Ries, S.K. Superoxide dismutases: I. Occurrence in higher plants. Plant Physiol. 1977, 59, 309-314. [CrossRef]

63. Nakano, Y.; Asada, K. Hydrogen peroxide is scavenged by ascorbate-specific peroxidase in spinach chloroplasts. Plant Cell Physiol. 1981, 22, 867-880.

64. Maehly, A.C.; Chance, B. The assay catalases and peroxidases. In Methods of Biochemical Analysis; Glick, D., Ed.; Interscience Pub: New York, NY, USA, 1954; Volume 1, pp. 357-424. 
65. Bradford, M.M. A rapid and sensitive method for the quantification of microgram quantities of protein utilizing the principle of protein-dye binding. Anal. Biochem. 1976, 72, 248-254. [CrossRef]

66. Velikova, V.; Yordanov, I.; Edreva, A. Oxidative stress and some antioxidant system in acid rain-treated bean plants: Protective role of exogenous polyamines. Plant Sci. 2000, 151, 59-66. [CrossRef]

67. Bates, L.S.; Waldren, R.P.; Teare, I.D. Rapid determination of free proline for water-stress studies. Plant Soil 1973, 39, 205-207. [CrossRef]

68. Kang, J.H.; Sugumaran, K.; Atulba, S.L.S.; Jeong, B.R.; Hwang, S.J. Light intensity and photoperiod influence the growth and development of hydroponically grown leaf lettuce in a closed-type plant factory system. Hortic. Environ. Biotechnol. 2013, 54, 501-509. [CrossRef]

69. Meng, X.; Xing, T.; Wang, X. The role of light in the regulation of anthocyanin accumulation in Gerbera hybrid. Plant Growth Regul. 2004, 44, 243-250. [CrossRef]

70. Nogues, S.; Backer, N.R. Effect of drought on photosynthesis in Mediterranean plants under UV-B radiation. J. Exp. Bot. 2000, 51, 1309-1317.

71. Baroowa, B.; Gogoi, N. Biochemical changes in two Vigna spp. during drought and subsequent recovery. Ind. J. Plant Physiol. 2013, 18, 319-325. [CrossRef]

72. Kolupaev, Y.E.; Fisova, E.N.; Yastreb, T.O.; Ryabchun, N.I.; Kirichenko, V.V. Effect of hydrogen sulfide donor on antioxidant state of wheat plants and their resistance to soil drought. Russ. J. Plant Physiol. 2019, 66, 59-66. [CrossRef] 